\title{
Vernonanthura polyanthes leaves aqueous extract enhances doxorubicin genotoxicity in somatic cells of Drosophila melanogaster and presents no antifungal activity against Candida spp.
}

\author{
I. J. Guerra-Santos ${ }^{a, b}$, J. D. Rocha ${ }^{a}$, C. R. Vale, W. C. Sousa ${ }^{a}$, A. M. Teles ${ }^{d}$, L. Chen-Chen , \\ S. Carvalho ${ }^{c}$ and E. F. L. C. Bailão $o^{a, e *}$ \\ aUniversidade Estadual de Goiás - UEG, Câmpus Iporá, Av. R2 Q.1, Jardim Novo Horizonte II, \\ CEP 76200-000, Iporá, GO, Brazil \\ 'Instituto Federal Goiano - IF Goiano, Câmpus de Rio Verde, Av. Sul Goiânia, Km 1, Zona Rural, \\ CEP 75901-970, Rio Verde, GO, Brazil
}

${ }^{\text {c} D e p a r t a m e n t o ~ d e ~ B i o l o g i a ~ G e r a l, ~ I n s t i t u t o ~ d e ~ C i e ̂ n c i a s ~ B i o l o ́ g i c a s ~ I, ~ U n i v e r s i d a d e ~ F e d e r a l ~ d e ~ G o i a ́ s ~-~ U F G, ~}$ Campus II, Samambaia, saída para Nerópolis, Km 13, CEP 74001-970, Goiânia, GO, Brazil

dDepartamento de Botânica, Instituto de Ciências Biológicas I, Universidade Federal de Goiás - UFG, Campus II, Samambaia, saída para Nerópolis, Km 13, CEP 74001-970, Goiânia, GO, Brazil

'Universidade Estadual de Goiás - UEG, Câmpus Henrique Santillo, Br 153, 3105 , Fazenda Barreiro do Meio, CEP 75132-903, Anápolis, GO, Brazil

*e-mail: elisaflavia@gmail.com

Received: March 23, 2015 - Accepted: July 31, 2015 - Distributed: November 30, 2016

(With 2 figures)

\begin{abstract}
Vernonanthura polyanthes (Spreng.) A.J. Vega \& Dematt. (Asteraceae), known as "assa-peixe", has been used in ethnomedicine for the treatment of various diseases such as bronchitis, pneumonia, hemoptysis, persistent cough, internal abscesses, gastric and kidney stone pain. Moreover, some studies demonstrated that species of Genus Vernonia present antifungal activity. Due to the biological relevance of this species, the aim of this study was to investigate the toxic, genotoxic, antigenotoxic and antifungal potential of $V$. polyanthes leaves aqueous extract in somatic cells of Drosophila melanogaster or against Candida spp. The aqueous extract of the plant showed no toxic, genotoxic and antigenotoxic activity in the experimental conditions tested using the wing somatic mutation and recombination test (SMART/wing). However, when the extract was associated with doxorubicin, used in this work as a positive control, the mutagenic potential of doxorubicin was enhanced, increasing the number of mutations in D. melanogaster somatic cells. In the other hand, no inhibitory activity against Candida spp. was observed for $V$. polyanthes leaves aqueous extract using agar-well diffusion assay. More studies are necessary to reveal the components present in the V. polyanthes leaves aqueous extract that could contribute to potentiate the doxorubicin genotoxicity.
\end{abstract}

Keywords: assa-peixe, Asteraceae, Cerrado, SMART/wing test, Vernonia polyanthes.

\author{
O extrato aquoso das folhas de Vernonanthura polyanthes \\ potencializa a genotoxicidade da doxorrubicina em células \\ somáticas de Drosophila melanogaster e não apresenta atividade \\ antifúngica contra Candida spp.
}

\section{Resumo}

Vernonanthura polyanthes (Spreng.) A.J. Vega \& Dematt. (Asteraceae), conhecida como "assa-peixe", tem sido utilizada na medicina popular para o tratamento de várias doenças, como bronquite, pneumonia, hemoptise, tosse persistente, abcessos internos, afecções gástricas e cálculo renal. Além disso, alguns estudos já demonstraram que espécies do Gênero Vernonia apresentam atividade antifúngica. Devido à relevância biológica dessa espécie, o objetivo deste estudo foi investigar os efeitos citotóxico, genotóxico, antigenotóxico e antifúngico do extrato aquoso das folhas de $V$. polyanthes em células somáticas de Drosophila melanogaster ou contra Candida spp. O extrato aquoso da planta não apresentou atividade citotóxica, genotóxica e antigenotóxica nas condições experimentais testadas usando o teste de recombinação e mutação somática em asa (SMART-asa). No entanto, quando o extrato foi associado com a doxorrubicina, utilizada neste trabalho como controle positivo, o potencial mutagênico da doxorrubicina foi potencializado, aumentando o 
número de mutações em células somáticas de D. melanogaster. Por outro lado, nenhuma atividade inibitória contra Candida spp. foi observada utilizando o extrato aquoso das folhas de $V$. polyanthes por meio do método de difusão em ágar. Mais estudos são necessários para desvendar os componentes presentes no extrato aquoso das folhas de $V$. polyanthes que possam contribuir para potencializar a genotoxicidade da doxorrubicina.

Palavras-chave: assa-peixe, Asteraceae, Cerrado, teste SMART/asa, Vernonia polyanthes.

\section{Introduction}

Vernonanthura polyanthes (Spreng.) A.J. Vega \& Dematt. [synonymous of Vernonanthura phosphorica (Vell.) H. Rob. according to Vega and Dematteis (2010)] belongs to the plant family Asteraceae and is popularly known as "assa-peixe". Due to the complexity of the Vernonia Genus, including around 1000 species (Keeley and Jones, 1979), Robinson (1999) segregated most of its South America species in 22 new genera, including Vernonathura, and after Vernonia polyanthes was combined as Vernonanthura polyanthes (Vega and Dematteis, 2010), the focus of this work. Metabolomic investigation corroborates the taxonomical classification, suggesting that Vernonia polyanthes should be considered as belonging to the Vernonanthura genus (Martucci et al., 2014).

The species belonging to Vernonia Genus can be found in a wide range of habitats of broad ecological diversity and climatic conditions, but especially in tropical regions. Many of them are used as food and medicine (Toyang and Verpoorte, 2013). It has been reported that plants belonging to Vernonia Genus presents a plenty of bioactivities, including antiplasmodial, antileishmanial, antischistosomial, cytotoxicity, antimicrobial and anti-inflammatory (Toyang and Verpoorte, 2013). The Vernonanthura species represent the "assa-peixes" used in Brazil in the composition of syrups for the treatment of flus and colds (Leitão et al., 2014). V. polyanthes is a plant common in Minas Gerais, São Paulo, Mato Grosso and Goiás, occurring primarily in Cerrado biome. This species is a shrub with oval leaves, rough and hairy spear-shaped. The white or pink inflorescences are arranged at the apices of the branches in small capitula (Alves and Neves, 2003).

$V$. polyanthes leaves and roots in decoction or infusion are used in ethnomedicine to treat bronchitis, persistent coughs, pneumonia, kidney stones, gastric disorders, malaria, fever, wounds, fractures, sprains, bruises and dislocations. In addition, the plant is indicated by common sense as diuretic and anti-rheumatic (Jorgetto et al., 2011; Oliveira et al., 2011; Slongo and Hoscheid, 2012). It has been demonstrated that $V$. polyanthes is a potential vasodilatation agent, able to manage blood pressure (Romanezi da Silveira et al., 2003). Moreover, the plant presents antiulcer effect (Barbastefano et al., 2007), and antinociceptive and anti-inflammatory activities (Temponi et al., 2012). Phytochemicals studies showed that $V$. polyanthes presents flavonoids (flavonols and flavones), sesquiterpene lactones, chlorogenic acids and phenolic acid (protocatechuic acid) (Igual et al., 2013; Martucci et al., 2014).

Due to $V$. polyanthes biological activities and extensive popular use, it is necessary to study the toxic, genotoxic and antigenotoxic activity of the leaves aqueous extract. Moreover some studies suggest that Cerrado plants could provide the basis for the production of new drugs (Silva et al., 2003). In that way, results obtained from genotoxicity tests are crucial to ensure the safe use of the plant (Maciel et al., 2002). One of the most widely used genotoxicity test is the wing Somatic Mutation And Recombination Test (SMART/wing) for genetic and chromosomal mutations and also somatic recombination detection in somatic cells of Drosophila melanogaster (Rocha et al., 2013).

The changes observed in SMART/wing test are induced in cells of the imaginal discs that after several mitotic divisions give rise to the wings of adults. The test is based on the identification of mutant phenotypes that are originated due to the occurrence of DNA damage, caused by the loss of larval heterozygous cells (Fonseca and Pereira, 2004; Ribeiro et al., 2003, 2009; Mendanha et al., 2010; Abreu et al., 2011; Alte et al., 2012). The test makes use of three D. melanogaster different strains: (i) multiple wing hairs ( $m w h$ ); (ii) flare-3 ( $\left.f r^{3}\right)$; and (iii) ORR/ORR. SMART/wing test is considered to be quick and inexpensive and gives reliable results, which are unambiguous and highly reproducible (Felício et al., 2014).

Many species of Asteraceae, including that ones belonging to Vernonia Genus, exhibit significant antifungal activity (Toyang and Verpoorte, 2013; Leitão et al., 2014). Many studies are being carried out to find plant species with potential antifungal activity (Silva et al., 2012; Höfling et al., 2010), because synthetic drugs may exhibit high toxicity to patients (Araújo et al., 2004). Substances more efficient against pathogenic microorganisms and less toxic to the patient could be isolated from vegetal species (Ostrosky, 2009). Studies performed by Ogundare et al. (2006) demonstrated that bark extracts from Vernonia tenoreana inhibited the growth of Candida albicans. Furthermore, it was demonstrated that other Cerrado plants, such as Lafoensia pacari (pacari) and Brossimum gaudichaudii (mama-cadela) extracts, also inhibited the growth of Candida spp. yeasts (Silva et al., 2012). These results point to the need for more studies on the utilization of Cerrado species for antifungal purposes. Candida spp. are of great importance for public health, since candidiasis is the third systemic mycosis in number of deaths (Prado et al., 2009) and vulvovaginal candidiasis is the first most common cause of fungal vaginal infections (Sobel, 2007).

Due to V.polyanthes therapeutic potential, the present study aimed to evaluate the toxic, genotoxic and antigenotoxic potential of $V$. polyanthes leaves aqueous extract in somatic cells of Drosophila melanogaster. The $V$. polyanthes leaves aqueous extract inhibitory activity against Candida spp. was also tested. 


\section{Material and Methods}

\subsection{Plant sample obtaining}

The plant sample was collected near Pôr do Sol lake in the city of Iporá, Goiás $\left(16^{\circ} 25^{\prime} \mathrm{S}, 51^{\circ} 06^{\prime} \mathrm{W}\right)$, in June 2012. After the botanical identification, a voucher specimen $\left(n^{\circ} 6519\right)$ was deposited in the herbarium of Universidade Estadual de Goiás, Câmpus Henrique Santillo. The collected leaves were dehydrated and pulverized.

\subsection{D. melanogaster strains and crosses}

The test makes use of three different strains of D. melanogaster: (i) multiple wing hairs: $y$; $m w h j$ ( $m w h, 3-0.3)$; (ii) flare-3: (flr3, 3-38.8) (flr3/In(3LR)TM3, ri pp sep I(3)89Aa bx34e and BdS); and (iii) ORR/ ORR: $\operatorname{fr} 3 / \operatorname{In}(3 L R) T M 3$, ri pp sep I(3)89Aa bx34e and BdS.

Two crosses were performed. In standard cross (ST), 80 female from $\mathrm{fl}^{3}$ lineage were crossed with 40 males from $m w h$ lineage. In high bioactivation (HB) crossing, 80 female ORR lineage were crossed with $40 \mathrm{mwh}$ males. In both crosses the following offspring was obtained: marked trans-heterozygous $(\mathrm{MH})$ with genetic constitution $m w h+/+f r^{3}$, which can be easily identified by the smooth wings (Ribeiro et al., 2003, 2009; Valadares, 2007; Mendanha et al., 2010).

\subsection{Survival curve}

To evaluate the toxic potential of the $V$. polyanthes leaves aqueous extract, $D$. melanogaster third-stage larvae originated from the two crosses (HB and ST) were collected $72 \mathrm{~h}$ after the beginning of oviposition, and washed in water with help of fine mesh stainless steel strainer. After, larvae were subjected to chronic treatment with different concentrations of $V$. polyanthes leaves aqueous extract. For this, $50 \mathrm{D}$. melanogaster larvae were placed in glass tubes $(2.5 \mathrm{~cm}$ diameter and $8.0 \mathrm{~cm}$ height) containing $0.9 \mathrm{~g}$ of mashed potatoes medium culture (Yoki SA, mashed potato flakes) hydrated with $3 \mathrm{~mL}$ of 7 different concentrations of $V$. polyanthes leaves aqueous extract for $48 \mathrm{~h}$. The aqueous extract of the plant was prepared similar to how people prepare the $V$. polyanthes tea: $3 \mathrm{~g}$ of dried and pulverized leaves boiled for $5 \mathrm{~min}$ in $150 \mathrm{~mL}$ of distilled water (ANVISA, 2011). From this stock solution at $0.02 \mathrm{~g} / \mathrm{mL}$, dilutions were made to obtain the following concentrations: $0.016 \mathrm{~g} / \mathrm{mL}, 0.012 \mathrm{~g} / \mathrm{mL}, 0.008 \mathrm{~g} / \mathrm{mL}$, $0.004 \mathrm{~g} / \mathrm{mL}, 0.002 \mathrm{~g} / \mathrm{mL}$ and $0.001 \mathrm{~g} / \mathrm{mL}$. Sterile distilled water was used as negative control. After seven days, the larvae that suffered metamorphosis into adult flies were counted as survivors. The test was performed in triplicate.

\subsection{Evaluation of genotoxicity and antigenotoxicity of $V$. polyanthes leaves aqueous extract}

ST and HB crosses were performed. The larvae from both crosses were subjected to chronic treatment, as described for the survival curve. For the assessment of genotoxicity and antigenotoxicity of the $V$. polyanthes leaves aqueous extract, three concentrations were tested: $0.012 \mathrm{~g} / \mathrm{mL}$,
$0.004 \mathrm{~g} / \mathrm{mL}$ and $0.001 \mathrm{~g} / \mathrm{mL}$. For the antigenotoxicity test, these extract concentrations were associated with $0.000125 \mathrm{~g} / \mathrm{mL}$ doxorubicin (DXR, Doxolen lyophilized, Eurofarma Laboratórios Ltda., São Paulo, Brazil, CAS No. 23214-92-8). Sterile distilled water was used as negative control and doxorubicin, a potent clastogenic agent of direct action (Dhawan et al., 2003), was used as positive control. When the adult flies were obtained, its wings were used for the preparation of the slides.

\subsection{Preparation of the slides}

The wings of flies were removed using an entomological forceps and a magnifying glass. The slides were kept on a hot plate between $40-45^{\circ} \mathrm{C}$ over a $24 \mathrm{~h}$ period, after this period, the slides were covered with coverslips containing Faure solution (30 g arabic gum, $16 \mathrm{~mL}$ glycerol, $200 \mathrm{~g}$ chloral hydrate $\left(\mathrm{Cl}_{3} \mathrm{CCH}(\mathrm{OH})_{2}\right)$ and $50 \mathrm{~mL}$ distilled water) for $24 \mathrm{~h}$ at $40-45^{\circ} \mathrm{C}$. After this period, the slides were examined for spots using a light microscope at 400x magnification.

\subsection{Statistical test}

The $\chi^{2}$ test was used to evaluate the mutagenic potential (Frei and Würgler, 1988). For the antimutagenic analysis, the frequencies of each type of spot for each treatment group were compared pairwise (DXR x $V$. polyanthes extract + DXR), using the nonparametric Mann-Whitney U-test and Wilcoxon rank sum tests (Frei and Würgler, 1995).

\subsection{Fungal strains and cultivation conditions}

For the antifungal potential analysis of $V$. polyanthes leaves aqueous extract, two species were selected: Candida albicans (ATCC 28367) and Candida parapsilosis (ATCC 22019). The fungus was maintained on Agar Sabouraud Dextrose (Himedia Laboratories Pvt. Ltd., India) at room temperature.

\subsection{Agar-well diffusion assay}

The fungal inoculum was prepared by suspension of colonies from a $48 \mathrm{~h}$ culture in $2 \mathrm{~mL}$ of sterile saline solution $(0.9 \% \mathrm{NaCl})$. The suspension was set at 0.5 of the McFarland scale (Silva et al., 2012). $30 \mu \mathrm{L}$ of this suspension was spread on Agar Sabouraud Dextrose supplemented with $10 \mu \mathrm{g} / \mathrm{mL}$ gentamicin. Then, six $6 \mathrm{~mm}$ diameter wells were made using a sterile tip (Alves et al., 2006). Each well was filled with $50 \mu \mathrm{L}$ of $V$. polyanthes leaves aqueous extract in seven different concentrations: $0.16 \mathrm{~g} / \mathrm{mL}, 0.08 \mathrm{~g} / \mathrm{mL}, 0.04 \mathrm{~g} / \mathrm{mL}, 0.02 \mathrm{~g} / \mathrm{mL}, 0.012 \mathrm{~g} / \mathrm{mL}$, $0.004 \mathrm{~g} / \mathrm{mL}$ and $0.001 \mathrm{~g} / \mathrm{mL}$. Nystatin oral suspension $100,000 \mathrm{IU} / \mathrm{mL}$ (Germed Pharmaceutical Ltda. Brazil) in a final dosage of $0.02 \mathrm{~g} / \mathrm{mL}$ (CLSI, 2008) and distilled water were used as positive and negative control, respectively. The plates were incubated at room temperature for $48 \mathrm{~h}$ and, then, the zones of inhibition were measured using a ruler. The zone sizes obtained in the presence of the $V$. polyanthes leaves aqueous extracts were compared to the values obtained for the positive control. This assay was performed in quadruplicate. 


\section{Results}

To assess the $V$. polyanthes toxicity, a survival curve of D. melanogaster larvae treated with different concentrations of $V$. polyanthes leaves aqueous extract was performed. After compiling the results of three independent experiments, the mean percentage of survivors was calculated. The survival curve showed that, under the conditions used in this work, $V$. polyanthes leaves aqueous extract presented no toxic activity in D. melanogaster larvae of both crosses, ST and $\mathrm{HB}$, when compared to the negative control (see Figure 1).

The $V$. polyanthes leaves aqueous extract genotoxicity was evaluated by ST ( $m w h / f l r 3)$ and $\mathrm{HB}(m w h / O R R)$ crosses, obtaining marker-heterozygous $(\mathrm{MH})$ flies $\left(m w h+/+f l r^{3}\right)$, presenting wild-type wings. According to the results, there was a significant increase in simple small spots (SSS), simple big spots (SBS) and twin spots (TWS), comparing to the negative control (distilled water). However, when compared the number of SSS, SBS and TWS of the treatments with the higher numbers obtained by the positive control (doxorubicin), one can suggest that $V$. polyanthes aqueous extract presented neither direct genotoxic effect, based on the analysis of ST crosses, nor indirect genotoxic effect, according to $\mathrm{HB}$ crosses, in somatic cells of D. melanogaster (as shown in Table 1).

$V$. polyanthes leaves aqueous extracts co-treatment with DXR (positive control) was used to evaluate the plant extract antigenotoxicity. After promoting the same crosses described for genotoxicity, a significant increase in SSS, SBS and TWS numbers was observed for the co-treatments, when compared to the positive control used alone (as shown in Table 2). In this way, the $V$. polyanthes leaves aqueous extracts may present no antigenotoxic activity, contrariwise, in the concentrations used in this work, the plant extract enhanced the doxorubicin genotoxicity in D. melanogaster somatic cells.

$V$. polyanthes leaves aqueous extract antifungal activity was tested in seven different concentrations
$(0.16 \mathrm{~g} / \mathrm{mL}, 0.08 \mathrm{~g} / \mathrm{mL}, 0.04 \mathrm{~g} / \mathrm{mL}, 0.02 \mathrm{~g} / \mathrm{mL}, 0.012 \mathrm{~g} / \mathrm{mL}$, $0.004 \mathrm{~g} / \mathrm{mL}$ and $0.001 \mathrm{~g} / \mathrm{mL}$ ). The conditions used in this work showed no inhibitory activity against $C$. albicans and C. parapsilosis, when compared with the positive control nystatin. The nystatin inhibition zone diameter was $13 \mathrm{~mm}$ \pm 1 and $14 \mathrm{~mm} \pm 1$ against C. albicans and C.parapsilosis, respectively (see Figure 2).

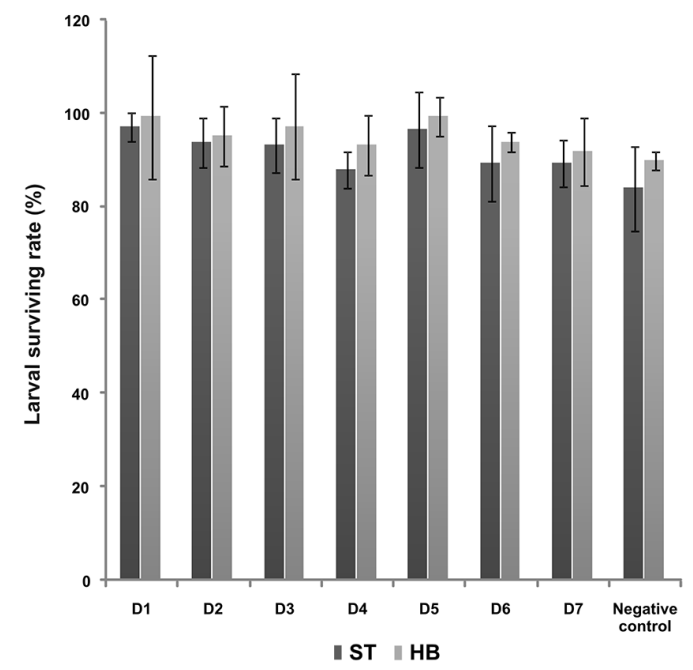

Figure 1. Survival curve of $D$. melanogaster larvae derived from the standard (ST) and high bioactivation (HB) crosses. The larvae obtained from ST and HB crosses were subjected to chronic treatment with different concentrations of $V$. polyanthes leaves aqueous extract. After seven days, the larvae that reached the adult stage were counted as survivors. Data are presented as means of triplicates percentage of surviving larvae + the standard deviation of triplicates. D1:0.02g/mL;D2:0.016g/mL;D3:0.012 g/mL;D4:0.008g/mL; D5: $0.004 \mathrm{~g} / \mathrm{mL}$; D6: $0.002 \mathrm{~g} / \mathrm{mL}$; D7: $0.001 \mathrm{~g} / \mathrm{mL}$; Negative control: sterile distilled water.

Table 1. Frequency of mutant spots observed in marker-heterozygous descendants of D. melanogaster from standard (ST) and high bioactivation (HB) crosses treated with different concentrations of $V$. polyanthes leaves aqueous extract.

\begin{tabular}{|c|c|c|c|c|c|c|c|c|c|c|c|c|c|}
\hline \multirow{4}{*}{ Treatment } & \multirow{4}{*}{$\begin{array}{c}\mathrm{N}^{\circ} \text { of } \\
\text { Indiv. } \\
\text { (N) }\end{array}$} & \multicolumn{12}{|c|}{ Frequency of mutant spots per individual $\left(\mathrm{N}^{0} \text { of spots }\right)^{\mathrm{a}}$} \\
\hline & & \multirow{2}{*}{\multicolumn{3}{|c|}{$\frac{\text { SSS }}{(1-2 \text { cells })^{b}}$}} & \multirow{2}{*}{\multicolumn{3}{|c|}{$\begin{array}{c}\text { SBS } \\
(>2 \text { cells })^{b} \\
\end{array}$}} & \multirow{3}{*}{\multicolumn{3}{|c|}{$\begin{array}{l}\text { TWS } \\
m=5\end{array}$}} & \multirow{3}{*}{\multicolumn{3}{|c|}{$\begin{array}{c}\text { TOS } \\
m=2\end{array}$}} \\
\hline & & & & & & & & & & & & & \\
\hline & & & $m=2$ & & & $m=5$ & & & & & & & \\
\hline Neg. Control & 40 & 0.00 & $(00)$ & & 0.03 & $(01)$ & & 0.05 & $(02)$ & & 0.08 & $(03)$ & \\
\hline Doxorrubicin & 40 & 4.85 & $(194)$ & + & 7.10 & $(284)$ & + & 6.95 & $(278)$ & + & 18.90 & $(756)$ & + \\
\hline $0.001 \mathrm{~g} / \mathrm{mL}$ & 40 & 0.03 & $(01)$ & - & 0.05 & (02) & - & 0.00 & $(00)$ & - & 0.08 & (03) & - \\
\hline $0.004 \mathrm{~g} / \mathrm{mL}$ & 40 & 0.03 & (01) & - & 0.00 & (00) & - & 0.03 & (01) & - & 0.05 & $(02)$ & - \\
\hline $\begin{array}{c}0.012 \mathrm{~g} / \mathrm{mL} \\
m w h / \mathrm{ORR}\end{array}$ & 40 & 0.00 & (00) & - & 0.00 & (00) & - & 0.00 & $(00)$ & - & 0.00 & $(00)$ & - \\
\hline Neg. Control & 40 & 0.03 & (01) & & 0.03 & (01) & & 0.00 & $(00)$ & & 0.05 & $(02)$ & \\
\hline Doxorrubicin & 40 & 3.50 & (140) & + & 4.78 & (191) & + & 4.75 & (190) & + & 13.03 & $(521)$ & + \\
\hline $0.001 \mathrm{~g} / \mathrm{mL}$ & 40 & 0.05 & $(02)$ & - & 0.00 & $(00)$ & - & 0.00 & $(00)$ & - & 0.05 & $(02)$ & - \\
\hline $0.004 \mathrm{~g} / \mathrm{mL}$ & 40 & 0.08 & (03) & - & 0.05 & (02) & - & 0.03 & (01) & - & 0.15 & (06) & - \\
\hline $0.012 \mathrm{~g} / \mathrm{mL}$ & 40 & 0.03 & $(01)$ & - & 0.00 & $(00)$ & - & 0.05 & $(02)$ & - & 0.08 & $(03)$ & - \\
\hline
\end{tabular}

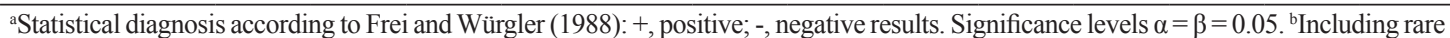
single spot $f r^{3}$. m: multiplication factor; SSS: simple small spots; SBS: simple big spots; TWS: twin spots; TOS: total spots. 
Table 2. Frequency of mutant spots observed in marker-heterozygous descendants of D. melanogaster from standard (ST) and high bioactivation (HB) crosses treated with different concentrations of $V$. polyanthes leaves aqueous extract associated with doxorubicin.

\begin{tabular}{|c|c|c|c|c|c|c|c|c|c|c|c|c|c|}
\hline \multirow{3}{*}{ Treatment } & \multirow{3}{*}{$\begin{array}{l}\mathbf{N}^{\circ} \text { of } \\
\text { Indiv. } \\
\text { (N) }\end{array}$} & \multicolumn{12}{|c|}{ Frequency of mutant spots per individual $\left(\mathrm{N}^{\circ} \text { of spots }\right)^{\mathrm{a}}$} \\
\hline & & \multicolumn{3}{|c|}{$\frac{\text { SSS }}{(1-2 \text { cells })^{b}}$} & \multicolumn{3}{|c|}{$\begin{array}{c}\text { SBS } \\
(>2 \text { cells })^{b}\end{array}$} & \multirow{2}{*}{\multicolumn{3}{|c|}{$\begin{array}{l}\text { TWS } \\
m=5\end{array}$}} & \multirow{2}{*}{\multicolumn{3}{|c|}{$\begin{array}{c}\text { TOS } \\
m=2\end{array}$}} \\
\hline & & & $m=2$ & & & $m=5$ & & & & & & & \\
\hline & & & & & & & & & & & & & \\
\hline Neg. Contr. & 40 & 0.00 & $(00)$ & & 0.03 & $(01)$ & & 0.05 & $(02)$ & & 0.08 & $(03)$ & \\
\hline Doxorrubicin & 40 & 4.85 & $(194)$ & + & 7.10 & $(284)$ & + & 6.95 & $(278)$ & + & 18.90 & $(756)$ & + \\
\hline$+0.001 \mathrm{~g} / \mathrm{ml}$ & 40 & 16.75 & $(670)$ & + & 23.60 & (944) & + & 23.65 & $(946)$ & + & 64.00 & $(2560)$ & + \\
\hline$+0.004 \mathrm{~g} / \mathrm{ml}$ & 40 & 11.30 & $(452)$ & + & 11.70 & $(468)$ & + & 11.00 & $(440)$ & + & 34.00 & $(1360)$ & + \\
\hline $\begin{array}{c}+0.012 \mathrm{~g} / \mathrm{ml} \\
m w h / \mathrm{ORR}\end{array}$ & 40 & 20.30 & (812) & + & 10.13 & $(405)$ & + & 8.80 & $(352)$ & + & 39.23 & (1569) & + \\
\hline Neg. Contr. & 40 & 0.03 & (01) & & 0.03 & (01) & & 0.00 & $(00)$ & & 0.05 & (02) & \\
\hline Doxorrubicin & 40 & 3.50 & (140) & + & 4.78 & (191) & + & 4.75 & (190) & + & 13.03 & $(521)$ & + \\
\hline$+0.001 \mathrm{~g} / \mathrm{ml}$ & 40 & 25.20 & (1008) & + & 16.60 & $(664)$ & + & 11.35 & $(454)$ & + & 53.15 & (2126) & + \\
\hline$+0.004 \mathrm{~g} / \mathrm{ml}$ & 40 & 18.65 & (746) & + & 8.83 & (353) & + & 8.28 & $(331)$ & + & 35.75 & $(1430)$ & + \\
\hline$+0.012 \mathrm{~g} / \mathrm{ml}$ & 40 & 18.63 & $(745)$ & + & 9.05 & $(362)$ & + & 8.48 & (339) & + & 36.15 & (1446) & + \\
\hline
\end{tabular}

${ }^{a}$ Statistical diagnosis according to Frei and Würgler (1988): +, positive; -, negative results. Significance levels $\alpha=\beta=0.05$.

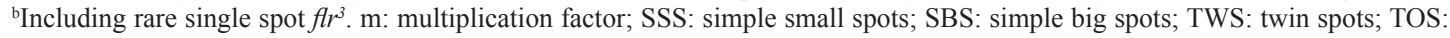
total spots.

\section{C. albicans}
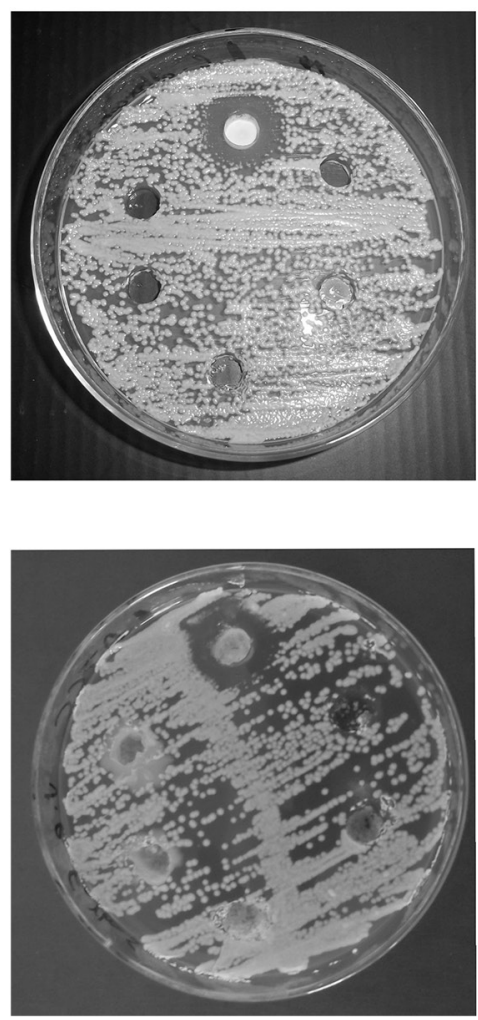

\section{C. parapsilosis}
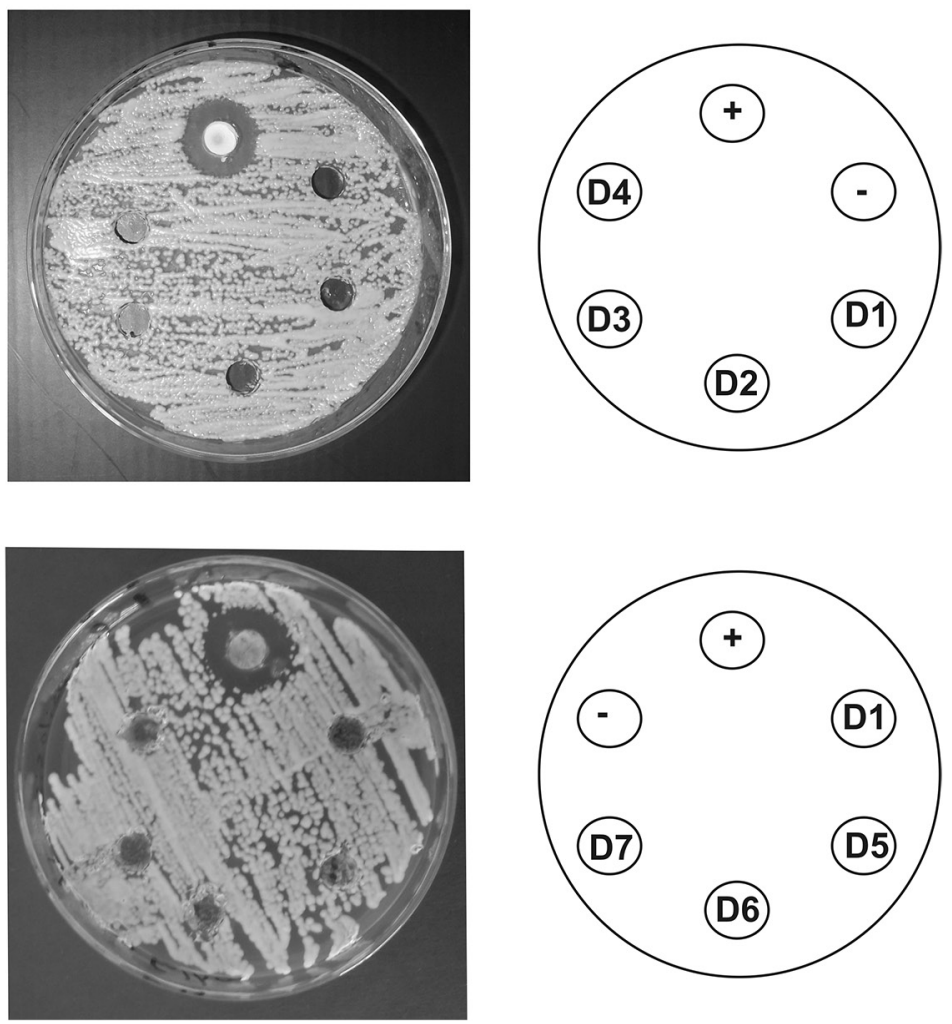

Figure 2. $V$. polyanthes leaves aqueous extract presents no antifungal activity against Candida spp. C. albicans and C. parapsilosis were cultivated on Sabouraud Dextrose agar for $48 \mathrm{~h}$. Then, the yeasts were spreaded on this media in presence of seven different concentrations of $V$. polyanthes leaves aqueous extract. After $48 \mathrm{~h}$, the zones of inhibition were measured using a ruler. Nystatin and distilled water were used as positive $(+)$ and negative (-) control, respectively. D1: $0.02 \mathrm{~g} / \mathrm{mL}$; D2: $0.012 \mathrm{~g} / \mathrm{mL}$; D3: $0.004 \mathrm{~g} / \mathrm{mL}$; D4: $0.001 \mathrm{~g} / \mathrm{mL}$; D5: $0.04 \mathrm{~g} / \mathrm{mL}$; D6: $0.08 \mathrm{~g} / \mathrm{mL}$; D7: $0.16 \mathrm{~g} / \mathrm{mL}$. 


\section{Discussion}

$V$. polyanthes leaves aqueous extract presented no toxic, genotoxic or antigenotoxic activity in D. melanogaster somatic cells under the conditions used in this work. Similarly, Vernonia condensata leaves aqueous extract did not present mutagenic potential using Salmonella/microsome assay (Monteiro et al., 2001). Moreover, the aqueous extract of Vernonia amygdalina and the methanol extract of Vernonia cineria present no toxicity in murine model (Amole et al., 2006; Rajamurugan et al., 2011). However, previous study with Swiss albinus mice demonstrated that $V$. polyanthes leaves hydroalcoholic extract presented a moderated genotoxic effect only in concentrations higher than $1500 \mathrm{mg} / \mathrm{kg}$ (Jorgetto et al., 2011). And when a sesquiterpene lactone, glaucolide B, was isolated from Vernonia eremophila, the molecule presented genotoxic and cytotoxic activities in vitro using human cultured lymphocytes, but did not present genotoxicity in vivo when bone marrow cells from BALB/c mice were analyzed (Burim et al., 1999).

These data suggest that the plant specie, the preparation method of the leaves extract and the model organism could influence the toxicity/genotoxicity responses. Some compounds may be present in one species and absent in another. It has been observed, for example, that $V$. polyanthes was the only species with presence of flavones chrysoeriol-7-O-glycuronyl, acacetin-7-O-glycuronyl and sesquiterpenes lactones piptocarphin A and piptocarphin B among ten Vernonia species studied by Martucci et al. (2014). Glaucolide A was detected only in $V$. brasiliana and $V$. polyanthes in this same study (Martucci et al., 2014). Furthermore, the extraction method using methanol described by Igual et al. (2013), for example, favors extraction of compounds stored in glandular trichomes, such as sesquiterpene lactones. In this way, the aqueous extract used in this work may have not favored the extraction of toxic/genotoxic compound(s).

Although V.polyanthes leaves aqueous extract presented no toxic, genotoxic or antigenotoxic activity, it enhanced doxorubicin genotoxicity in D. melanogaster somatic cells. Similar results have been demonstrated to Piper cubeba, Lycopersicon esculentum and Tabebuia impetiginosa using the same organism model. When (-)-cubebin, a compound isolated from Piper cubeba seeds, was combined with DXR, the number of mutant spots increased (Rezende et al., 2011). The extract of organic tomato Lycopersicon esculentum when combined with DXR also potentiates the genotoxic effect of this drug (Dutra et al., 2009). T. impetiginosa alone did not act as a genotoxin or an antigenotoxin, but it induced the DXR genotoxicity when associated with this mutagen (Sousa et al., 2009). Moreover, it was demonstrated, using micronucleus assay, that hydroalcoholic extract of Mikania glomerata (Asteraceae) aerial parts significantly increased DXR genotoxicity (Barbosa et al., 2012).

Plant extracts contain multiple components that can exert toxicity separately or synergistically (Cai et al., 2004;
Romero-Jiménez et al., 2005). In this way, co-administration of herb and therapeutic drugs may cause clinical risk to patients and so need to be investigated (Barbosa et al., 2012). But the components and mechanisms used by some plants to enhance DXR genotoxic effect were not revealed yet. DXR is a chemotherapeutic agent that induces single- and double-stranded DNA breaks (Rezende et al., 2011), after being metabolized by cytochrome P450 complex (Dutra et al., 2009). Interestingly, this enzyme complex is also responsible for DXR detoxification (Niitsu et al., 2000). It is proposed that plant components could (i) directly interact with cytochrome P450 enzymes involved in DXR metabolism or (ii) generate oxygen free radicals that could increase this enzymatic activity, both contributing to DXR mutagenicity enhancing (Sousa et al., 2009). In that way, the $V$. polyanthes extract used in this work may contain compound(s) that influence the DXR genotoxicity.

$V$. polyanthes leaves aqueous extract presented no antifungal activity against $C$. albicans and C. parapsilosis under the conditions used in this work. Similar results were observed by Sartori et al. (2003) using a methanolic extract of Acmela brasiliensis (Asteraceae) flowers. None of the fractions tested possessed activity against the yeasts tested, including C. albicans and Candida tropicalis. However, all fractions were active against dermatophytes (Sartori et al., 2003). Similarly, Vernonia cinerea leaves acetonic extract presented antifungal activity only against a strain of Candida glabrata (H05 flu R), but not against another strain of this fungus (H05 flu S) and against C. albicans, Candida krusei and A. fumigatus (Mini et al., 2010). Vernonia cinerea leaves methanolic extract was also tested and exhibited antifungal activity against C. albicans (Latha et al., 2011). The crude leaf and tuber dichloromethane, methanolic and aqueous extracts from Vernonia guineensis exhibited weak antifungal activity against Candida albicans, A. fumigatus and Trichophyton mentagrophytes; except for the dichloromethane and methanolic tuber extract, which showed moderate activity against $A$. fumigatus (Toyang et al., 2012).

These results suggest that different extracts of Vernonia species could present antifungal activity against different fungi species. So, more studies have to be developed using different $V$. polyanthes parts, or different forms of extraction, against different fungi groups, such as dermatophytes, to elucidate if this plant could inhibit any fungus growth.

In this study, we showed that $V$. polyanthes leaves aqueous extract could enhance DXR genotoxicity by components and mechanisms not revealed yet. Future work will focus on determine the substance(s) involved in this potentiating effect, since an understanding of components and mechanisms involved in herb-drug interactions is essential for clinical risk assessment (Barbosa et al., 2012). Moreover, further studies are needed to confirm the efficacy and/or risks of the use of this plant tea by the population, as well as to find alternatives to the rational use of this natural resource. 


\section{Acknowledgements}

We would like to thank Dr. Leonardo Luiz Borges for pulverizing the $V$. polyanthes dehydrated leaves, and Dr. Maria do Rosário Rodrigues Silva for providing Candida spp. strains. We are also grateful to Universidade Estadual de Goiás (UEG) for the scholarships (PBIT/UEG) granted to Isis de Jesus Guerra and Jamira Dias Rocha during the execution of this work.

\section{References}

ABREU, B.R.R., THOMÉ, S., LEHMANN, M. and DIHL, R.R., 2011. Investigação da atividade mutagênica de dois agentes antibacterianos em células somáticas de Drosophila melanogaster. Revista de Iniciação Científica da ULBRA, vol. 1, pp. 69-76.

AGÊNCIA NACIONAL DE VIGILÂNCIA SANITÁRIA ANVISA, 2011. Formulário de fitoterápicos da farmacopeia brasileira. Brasília. $126 \mathrm{p}$.

ALTE, M.A., THOMÉ, S., ABREU, B.R.R., LEHMANN, M. and DIHL, R.R., 2012. Avaliação da atividade tóxico-genética da enrofloxacina. Revista de Iniciação Científica da ULBRA, vol. 10, pp. 21-26.

ALVES, P.M., LEITE, P.H.A.S., PEREIRA, J.V., PEREIRA, L.F., PEREIRA, M.S.V., HIGINO, J.S. and LIMA, E.O., 2006. Atividade antifúngica do extrato de Psidium guajava Linn. (goiabeira) sobre leveduras do gênero Candida da cavidade oral: uma avaliação in vitro. Revista Brasileira de Farmacognosia, vol. 16, no. 2, pp. 192-196. http://dx.doi.org/10.1590/S0102-695X2006000200010.

ALVES, V F.G. and NEVES, L.J., 2003. Anatomia Foliar de Vernonia Polyanthes Less (Asteraceae). Universidade Rural do Rio de Janeiro. Revista da Universidade Rural: Série Ciências da Vida, vol. 22, pp. 1-8.

AMOLE, O.O., IZEGBU, M.C., ONAKOYA, J.A.A. and DADA, M.O., 2006. Toxicity studies of the aqueous extract of Vernonia amygdalina. Biomedical Research, vol. 17, pp. 39-40.

ARAÚJO, J.C.L.V., LIMA, E.O., CEBALLOS, B.S.O., FREIRE, K.R.L., SOUZA, E.L. and SANTOS-FILHO, L., 2004. Ação antimicrobiana de óleos essenciais sobre microrganismos potencialmente causadores de infecções oportunistas. Revista de Patologia Tropical, vol. 33, pp. 55-64.

BARBASTEFANO, V., COLA, M., LUIZ-FERREIRA, A., FARIAS-SILVA, E., HIRUMA-LIMA, C.A., RINALDO, D., VILEGAS, W. and SOUZA-BRITO, A.R.M., 2007. Vernonia polyanthes as a new source of antiulcer drugs. Fitoterapia, vol. 78, no. 7-8, pp. 545-551. http://dx.doi.org/10.1016/j.fitote.2007.07.003. PMid:17904766.

BARBOSA, L.C., MORAIS, M.D., PAULA, C.A., FERREIRA, M.C.S., JORDÃO, A.A., SILVA, M.L.A., BASTOS, J.K., SILVAFILHO, A.A. and CECCHI, A.O., 2012. Mikania glomerata Sprengel (Asteraceae) influences the mutagenicity induced by doxorubicin without altering liver lipid peroxidation or antioxidant levels. Journal of Toxicology and Environmental Health. Part A., vol. 75, no. 16-17, pp. 1102-1109. http://dx.doi.org/10.1080/152 87394.2012.697842. PMid:22852859.

BURIM, R.V., CANALLE, R., LOPES, J.L.C. and TAKAHASHI, C.S., 1999. Genotoxic action of the sesquiterpene lactone glaucolide $\mathrm{B}$ on mammalian cells in vitro and in vivo. Genetics and Molecular
Biology, vol. 22, no. 3, pp. 401-406. http://dx.doi.org/10.1590/ S1415-47571999000300020.

CAI, Z., TSUNG, E.F., MARINESCU, V.D., RAMONI, M.F., RIVA, A. and KOHANE, I.S., 2004. Bayesian approach to discovering pathogenic SNPs in conserved protein domains. Human Mutation, vol. 24, no. 2, pp. 178-184. http://dx.doi. org/10.1002/humu.20063. PMid:15241800.

CLINICAL AND LABORATORY STANDARDS INSTITUTE - CLSI, 2008. Method for broth dilution antifungal susceptibility testing of yeasts: approved standard-third edition M27-A3. Wayne: CLSI.

DHAWAN, A., KAYANI, M.A., PARRY, J.M., PARRY, E. and ANDERSON, D., 2003. Aneugenic and clastogenic effects of doxorubicin in human lymphocytes. Mutagenesis, vol. 18, no. 6, pp. 487-490. http://dx.doi.org/10.1093/mutage/geg024. PMid:14614182.

DUTRA, E.S., DIAS, C.D., ARAÚJO, B.C., CASTRO, A.J.S. and NEPOMUCENO, J.C., 2009. Effect of organic tomato (Lycopersicon esculentum) extract on the genotoxicity of doxorubicin in the Drosophila wing spot test. Genetics and Molecular Biology, vol. 32, no. 1, pp. 133-137. http://dx.doi.org/10.1590/S141547572009005000008. PMid:21637658.

FELÍCIO, D.C., PEREIRA, D.S., ASSUMPÇÃO, A.M., JESUSMORALEIDA, F.R., QUEIROZ, B.Z., SILVA, J.P., ROSA, N.M.B., DIAS, J.M.D. and PEREIRA, L.S.M., 2014. Systemic inflammation and physical function in community elderly women. Inflammation \& Cell Signaling, vol. 1, pp. 1-3.

FONSECA, C.A. and PEREIRA, D.G., 2004. Aplicação da genética toxicológica em planta com atividade medicinal. Infarma, vol. 16 , pp. 7-8.

FREI, H. and WÜRGLER, F.E., 1988. Statistical methods to decide whether mutagenicity test data from Drosophila assays indicate a positive, negative, or inconclusive result. Mutation Research, vol. 203, no. 4, pp. 297-308. http://dx.doi.org/10.1016/01651161(88)90019-2. PMid:3136327.

FREI, H. and WÜRGLER, F.E., 1995. Optimal experimental design and sample size for the statistical evaluation of data from somatic mutation and recombination tests (SMART) in Drosophila. Mutation Research, vol. 334, no. 2, pp. 247-258. http://dx.doi. org/10.1016/0165-1161(95)90018-7. PMid:7885379.

HÖFLING, J.F., ANIBAL, P.C., OBANDO-PEREDA, G.A., PEIXOTO, I.A., FURLETTI, V.F., FOGLIO, M.A. and GONÇALVES, R.B., 2010. Antimicrobial potential of some plant extracts against Candida species. Brazilian Journal of Biology $=$ Revista Brasileira de Biologia, vol. 70, no. 4, pp. 1065-1068. http:// dx.doi.org/10.1590/S1519-69842010000500022. PMid:21180915.

IGUAL, M.O., MARTUCCI, M.E.P., COSTA, F.B. and GOBBONETO, L., 2013. Sesquiterpene lactones, chlorogenic acids and flavonoids fromleaves of Vernonia polyanthes Less (Asteraceae). Biochemical Systematics and Ecology, vol. 51, pp. 94-97. http:// dx.doi.org/10.1016/j.bse.2013.08.018.

JORGETTO, G.V., BORIOLO, M.F.G., SILVA, L.M., NOGUEIRA, D.A., JOSÉ, T.D.S., RIBEIRO, G.E., OLIVEIRA, N.M.S. and FIORINI, J.E., 2011. Ensaios de atividade antimicrobiana in vitro e mutagênica in vivo com extrato de Vernonia polyanthes Less (Assa-peixe). Revista Instituto Adolfo Lutz, vol. 70, pp. 53-61.

KEELEY, S.C. and JONES, S., 1979. Distribution of pollen types in Vernonia (Vernonieae - Compositae). Systematic Botany, vol. 4, no. 3, pp. 195-202. http://dx.doi.org/10.2307/2418418. 
LATHA, L.Y., DARAH, I., JAIN, K. and SASIDHARAN, S., 2011. Effects of Vernonia cinerea Less methanol extract on growth and morphogenesis of Candida albicans. European Review for Medical and Pharmacological Sciences, vol. 15, no. 5, pp. 543549. PMid:21744750.

LEITÃO, F., LEITÃO, S.G., FONSECA-KRUEL, V.S., SILVA, I.M. and MARTINS, K., 2014. Medicinal plants traded in the open-air markets in the State of Rio de Janeiro, Brazil: an overview on their botanical diversity and toxicological potential. Revista Brasileira de Farmacognosia, vol. 24, no. 2, pp. 225-247. http:// dx.doi.org/10.1016/j.bjp.2014.04.005.

MACIEL, M.A.M., PINTO, A.C., VEIGA, V.E. Jr., GRYNBERG, N.F. and ECHEVARRIA, A., 2002. Plantas medicinais: a necessidade de estudos multidisciplinares. Química Nova, vol. 23, no. 3, pp. 429-438. http://dx.doi.org/10.1590/S0100-40422002000300016.

MARTUCCI, M.E.P., VOS, R.C.H., CAROLLO, C.A. and GOBBONETO, L., 2014. Metabolomics as a Potential Chemotaxonomical Tool: Application in the Genus Vernonia Schreb. PLoS One, vol. 9, no. 4, pp. 1-8. http://dx.doi.org/10.1371/journal.pone.0093149. PMid:24736747.

MENDANHA, D.M., FERREIRA, H.D., FELÍCIO, L.P., SILVA, E.M., PEREIRA, D.G., NUNES, W.B. and CARVALHO, S., 2010. Modulatory effect of Byrsonima verbascifolia (Malpighiaceae) against damage induced by doxorubicin in somatic cells of Drosophila melanogaster. Genetics and Molecular Research, vol. 9, no. 1, pp. 69-77. http://dx.doi.org/10.4238/vol9-1gmr678. PMid:20092036.

MINI, N.V., IDA, B., SEEMA, D., SHITAL, D., RIVA, D.S. and ASTRIDA, R., 2010. Antimicrobial activity of ten common herbs, commonly known as 'Dashapushpam' from Kerala, India. African Journal of Microbiological Research, vol. 4, pp. 2357-2362.

MONTEIRO, M.H.D., GOMES-CARNEIRO, M.R., FELZENSZWALB, I., CHAHOUD, I. and PAUMGARTTEN, F.J.R., 2001. Toxicological evaluation of a tea from leaves of Vernonia condensata. Journal of Ethnopharmacology, vol. 74, no. 2, pp. 149-157. http://dx.doi. org/10.1016/S0378-8741(00)00363-9. PMid:11167033.

NIITSU, N., OKABE-KADO, J., NAKAYAMA, M., WAKIMOTO, N., SAKASHITA, A., MASEKI, N., MOTOYOSHI, K., UMEDA, M. and HONMA, Y., 2000. Plasma levels of the differentiation inhibitory factor $\mathrm{nm} 23-\mathrm{H} 1$ protein and their clinical implications in acute myelogenous leukemia. Blood, vol. 96, no. 3, pp. 10801086. PMid:10910925.

OGUNDARE, A.O., ADETUYI, F.C. and AKINYOSOYE, F.A., 2006. Antimicrobial activities of Vernonia tenoreana. African Journal of Biotechnology, vol. 5, pp. 1663-1668.

OLIVEIRA, A.K.M., OLIVEIRA, N.A., RESENDE, U.M. and MARTINS, P.F.R.B., 2011. Ethnobotany and traditional medicine of the inhabitants of the Pantanal Negro sub-region and the raizeiros of Miranda and Aquidauna, Mato Grosso do Sul, Brazil. Brazilian Journal of Biology $=$ Revista Brasileira de Biologia, vol. 71, no. 1, suppl., pp. 283-289. http://dx.doi.org/10.1590/ S1519-69842011000200007. PMid:21537601.

OSTROSKY, E.A., 2009. Avaliação da eficácia e segurança do extrato de folhas de R. rosaefolius Sm. visando a aplicação como conservante em produtos cosméticos. São Paulo: Faculdade de Ciências Farmacêuticas, Universidade de São Paulo, 175 p. $\mathrm{PhD}$ Thesis.

PRADO, M., SILVA, M.B., LAURENTI, R., TRAVASSOS, L.R. and TABORDA, C.P., 2009. Mortality due to systemic mycoses as a primary cause of death or in association with AIDS in Brazil: a review from 1996 to 2006. Memórias do Instituto Oswaldo Cruz, vol. 104, no. 3, pp. 513-521. http://dx.doi.org/10.1590/ S0074-02762009000300019. PMid:19547881.

RAJAMURUGAN, R., SELVAGANABATHY, N., KUMARAVEL, S., RAMAMURTHY, C., SUJATHA, V., SURESH KUMAR, M. and THIRUNAVUKKARASU, C., 2011. Identification, quantification of bioactive constituents, evaluation of antioxidant and in vivo acute toxicity property from the methanol extract of Vernonia cinerea leaf extract. Pharmaceutical Biology, vol. 49, no. 12, pp. 1311-1320. http://dx.doi.org/10.3109/13880209.201 1.604334. PMid:22077167.

REZENDE, A.A., E SILVA, M.L., TAVARES, D.C., CUNHA, W.R., REZENDE, K.C., BASTOS, J.K., LEHMANN, M., DE ANDRADE, H.H., GUTERRES, Z.R., SILVA, L.P. and SPANÓ, M.A., 2011. The effect of the dibenzylbutyrolactolic lignan (_)-cubebin on doxorubicin mutagenicity and recombinogenicity in wing somatic cells of Drosophila malanogaster. Food and Chemical Toxicology, vol. 49, no. 6, pp. 1235-1241. http://dx.doi. org/10.1016/j.fct.2011.03.001. PMid:21385598.

RIBEIRO, L.R., SALVADORI, D.M.F. and MARQUES, E.K., 2003. Mutagênese ambiental. Canoas: ULBRA. 356 p.

RIBEIRO, V., VIERA, I.L.B.F., PASSOS, D.C.S., SILVA, E.M., VALE, C.R., FELÍCIO, L.P., FERREIRA, H.D., VIEIRA, P.M. and CARVALHO, S., 2009. Ausência da mutagenicidade de Solanum paniculatum L. em células somáticas de Drosophila melanogaster: SMART/ASA. Revista de Biologia Neotropical, vol. 6, pp. 27-33.

ROBINSON, H., 1999. Generic and subtribal classification of American Vernonieae. Smithsonian Contributions to Botany, no. 89, pp. 1-116. http://dx.doi.org/10.5479/si.0081024X.89.

ROCHA, L.D.L.S., FARIA, J.C.N.M., CRUZ, A.H.S., REIS, A.A.S. and SANTOS, R.S., 2013. Drosophila: um importante modelo biológico para a pesquisa e o ensino de genética. Scire Salutes, vol. 3, no. 1, pp. 37-48. http://dx.doi.org/10.6008/ ESS2236-9600.2013.001.0004.

ROMANEZI DA SILVEIRA, R., FOGLIO, M.A. and GONTIJO, J.A.R., 2003. Effect of the crude extract of Vernonia polyanthes Less. on blood pressure and renal sodium excretion in unanesthetized rats. Phytomedicine, vol. 10, no. 2-3, pp. 127-131. http://dx.doi. org/10.1078/094471103321659825. PMid:12725565.

ROMERO-JIMÉNEZ, M., CAMPOS-SÁNCHEZ, J., ANALLA, M., MUÑOZ-SERRANO, A. and ALONSO-MORAGA, A., 2005. Genotoxicity and anti-genotoxicity of some traditional medicinal herbs. Mutation Research, vol. 585, no. 1-2, pp. 147-155. http:// dx.doi.org/10.1016/j.mrgentox.2005.05.004. PMid:16005256.

SARTORI, M.R.K., PRETTO, J.B., CRUZ, A.B., BRESCIANI, L.F.V., YUNES, R.A., SORTINO, M., ZACCHINO, S.A. and CECHINEL FILHO, V., 2003. Antifungal activity of fractions and two pure compounds of flowers from Wedelia paludosa (Acmela brasiliensis) (Asteraceae). Die Pharmazie, vol. 58, no. 8, pp. 567-569. PMid:12967035.

SILVA, I.R., BITTENCOURT, A.C.S.P., DOMINGUEZ, J.M.L. and SILVA, S.B.M., 2003. Uma contribuição à gestão ambiental da costa do descobrimento (litoral sul do Estado da Bahia): avaliação da qualidade recreacional das praias. Geografia, vol. 28 , pp. 397-414.

SILVA, S.M.F.Q., PINHEIRO, S.M.B., QUEIROZ, M.V.F., PRANCHEVICIUS, M.C., CASTRO, J.G.D., PERIM, M.C. and CARREIRO, S.C., 2012. Atividade in vitro de extratos brutos de duas espécies vegetais do Cerrado sobre leveduras do gênero 
Candida. Ciência \& Saúde Coletiva, vol. 17, no. 6, pp. 16491656. http://dx.doi.org/10.1590/S1413-81232012000600028. PMid:22699655.

SLONGO, J.M. and HOSCHEID, J., 2012. Avaliação fitoquímica preliminar de extratos de folhas e raízes de Vernonanthura polyanthes obtidos por maceração, infusão e decocção. Revista de Fitoterapia, vol. 12, pp. 77.

SOBEL, J.D., 2007. Vulvovaginal candidosis. Lancet, vol. 369, no. 9577, pp. 1961-1971. http://dx.doi.org/10.1016/S01406736(07)60917-9. PMid:17560449.

SOUSA, N.C., REZENDE, A.A.A., SILVA, R.M.G., GUTERRES, Z.R., GRAF, U., KERR, W.E. and SPANÓ, M.A., 2009. Modulatory effects of Tabebuia impetiginosa (Lamiales, Bignoniaceae) on doxorubicin-induced somatic mutation and recombination in Drosophila melanogaster. Genetics and Molecular Biology, vol. 32, no. 2, pp. 382-388. http://dx.doi.org/10.1590/S141547572009005000042. PMid:21637695.

TEMPONI, L.G., POLI, L.P., SAKURAGUI, C.M. and COELHO, M.A.N., 2012. Araceae do Parque Estadual de Ibitipoca, Minas Gerais, Brasil. Rodriguésia, vol. 63, no. 4, pp. 957-969. http:// dx.doi.org/10.1590/S2175-78602012000400013.
TOYANG, N.J. and VERPOORTE, R., 2013. Review of the medicinal potentials of plants of the genus Vernonia (Asteraceae). Journal of Ethnopharmacology, vol.146, no. 3, pp. 681-723. PMid:23395623.

TOYANG, N.J., ATEH, E.N., KEISER, J., VARGAS, M., BACH, H., TANE, P., SONDENGAM, L.B., DAVIS, H., BRYANT, J. and VERPOORTE, R., 2012. Toxicity, antimicrobial and anthelmintic activities of Vernonia guineensis Benth. (Asteraceae) crude extracts. Journal of Ethnopharmacology, vol. 144, no. 3, pp. 700-704. http://dx.doi.org/10.1016/j.jep.2012.10.016. PMid:23107821.

VALADARES, B.L.B., 2007. Avaliação de derivados sintéticos da testosterona pelo teste de mutação e recombinação somática (SMART) em Drosophila melanogaster. Uberlândia: Programa de Pós-graduação em Genética e Bioquímica, Universidade Federal de Uberlândia, 113 p. PhD Thesis.

VEGA, A.J. and DEMATTEIS, M., 2010. The transfer of Vernonia perangusta to the genus Vernonanthura (Vernonieae, Asteraceae) and the correct name for Vernonanthura phosphorica. Phytotaxa, vol. 8, no. 1, pp. 46-50. http://dx.doi.org/10.11646/phytotaxa.8.1.5. 